\title{
Do Initial Public Offerings In Kenya Outperform The Market? A Longitudinal Analysis of Returns.
}

\author{
Francis Mambo Gatumo \\ United States International University P.O BOX 18321-00100 Nairobi.
}

\begin{abstract}
Reilly and Brown (2009) state that investors 's expected investment return is determined by time value of money, expected rate of inflation and the risk involved. Long run investors in Initial Public Offerings have longer time horizon, inflation is uncertain, but due to time factor, more risk is expected. The purpose of this study is to examine the long run performance of initial Public offerings in Kenya in order to determine whether they outperform the Nairobi securities Exchange (20) Index. Consequently, geometric mean returns were compared with Nairobi Securities Exchange (20) Index through buy and hold abnormal return (BHAR). The population of the study was all the initial Public offering firms listed between 2000 and 2014 in Nairobi Securities Exchange. Data for the listed firms was obtained from Capital Markets Authority (the capital markets regulator) in Kenya, and Nairobi securities exchange. The design of the study was explanatory. The findings were that the p-values $=0.46>0.05$ level of significance. Therefore, the long run return of initial Public offering in Kenya did not exceed the market return. Consequently, an investor in the Initial Public Offerings in Kenya can expect to obtain a return similar to the market return.
\end{abstract}

Keywords: Initial Public Offerings (IPOs), long run, Kenya, market index, outperformance, geometric mean return (GMR) buy and hold abnormal return (BHAR)

\section{Introduction}

An investor is curious to know the investment returns in the medium term in order to undertake investment rebalancing. Globally, capital seeker investors are interested with the capital gains accruing in their investments. Brav and Gompers (1997) alluded that long run IPO returns approximate the historical market returns. Ritter (1991) in USA and Paudyal et al.,( 1998) in Malaysia found long run underperformance of initial Public offerings. Paudyal et al.,( 1998), further argue that since the abnormal initial public offerings returns were casued by overoptimism, information flow reduce overoptimism and therefore drive the demand and prices downwards, resulting in IPO underperformance. In contrast, Levis (1993) and Espenlaubs, Gregory and Tonks (1998) find overperformance of IPOs in the long run in United Kingdom.

Long run underperformance of IPO returns is a correction of the misinformation that occurred at the time of issue of the IPO. Tim and Ritter (1995) aver that investors enter capital markets when Issuers have impressive financial results and shares are over valued. Window dressing hypothesis suggest that IPO firms inflate their accounting numbers to look better, but after issue, peformance falls, partly due to increased agency monitoring costs. The traditional investment wisdom that investors gain in the long run is, therefore, untested. The key question addresed in this paper is: can a two year horizon investor in IPOs in Kenya make gains, beyond the market index?

The existence of information asymmetry prevent IPO investors from accesing relevant investment information. Notwithstanding market information paucity, the public invest in IPOs. This paper will address the returns of an IPO investor who buy and hold on to the stock for a period of two years.

The rest of the paper is structured to include: literature review, methodology, results and findings and conclusions.

\section{Literature Review}

Otero and Mendez (2005) analyzed 52 IPO firms listed between 1987 to 1997 in Madrid Stock Exchange for 12 months, 36 months and 60 months. They found that for 12 months, the IPOs performed while for 36 months and 60 months, the IPOs underperformed. Gompers and Lerner(2003)examined 3661 USA IPO firms listed between 1935 and 1972 and established that IPOs underperformed when event time buy and hold abnormal returns was applied. However, when cumulative abnormal returns was applied, the underperformance disappears. They, also, observed that calendar time analysis showed that IPO returns are similar to the market return.Thomadakis, Nounis, and Gounopoulos (2012) analyzed 254 IPO firms listed in Greece between 1994 and 2002. Using both buy and hold abnormal return and cumulative abnormal return, they found that Greek IPOs outperform in the long run, however underperformance emerges. Berk and Peterle (2015) found long run underperform of IPOs. 
Do Initial Public Offerings In Kenya Outperform The Market? A Longitudinal Analysis Of Returns.

Omran,(2005) found negative abnormal returns for three and five year horizons. Omran finds that the negative abnormal returns were influenced by the IPO returns, subscription rate and price earnings ratio. The findings are consistent with behavior of investors who are optimistic at the issue, but become more pessimistic as more IPO relevant information is received.Barber and Lyon (1997) argue that test statistics based on abnormal retrunsusing market index are subject to misspecification. However, misspecification is minimized if the selected samples were from a specified population. In Kenya, Wamari (2014) analyzed 7 IPO firms listed between 2000 and 2006 and confirm IPO underperformance in the long run.

\section{Methodology}

Barber and Lyon (1977) used cumulative abnormal return (CAR), buy, and hold abnormal return (BHAR), but favour BHAR, because BHAR reflect the real experience of the investor. CAR ignore compounding while BHAR include the effects of compounding. $\mathrm{CAR}=\sum$ average return, while $\mathrm{BHAR}=\prod(1+$ raw total return )- $\prod(1+$ return of market $)$. Wamari (2014) used BHAR $=1 / \mathrm{N} \sum\left[\left(\prod(1+\mathrm{rtr})-\left(\prod(1+\mathrm{rm})\right]\right.\right.$ to represent BHAR. Barber and Lyon (1997) opinioned that CAR is a biased predictor, therefore they were advocating BHAR.n refer to the population while rtr is the raw total return of each IPO. Rm is the market return. They state that BHAR overestimates the outcome, particularly when the time horizon is large. Indeed, Strong (1992) define such analysis as event time approach. Event time studies are empirical investigation of relationship between the security prices and economic events.

This study analyzed 18 firms that were listed in Nairobi Securities Exchange between 2000 and 2014. The stock prices consisted of the offer price, closing price on the first day of trading, prices at December of the following year and stock prices of the second year. The Nairobi securities exchange (20) indd3ex provided the market return at issue, at the first day of trading, prices at December of first year and second year, respectively. The prices were obtained from the IPO prospectus in the Library of Capital Market Authority (the capital markets regulator in Kenya) and Nairobi Securities Exchange price listing. BHAR was tested for significance by use of $\mathrm{t}-\mathrm{BHAR}=\overline{B H A R} / 6 \mathrm{BHAR} / \sqrt{ } \mathrm{N}$. The design of the study was explanatory. Data was analyzedusing Statistical Package for Social Sciences (SPSS). The results were presented in tables.

\section{Descriptive Statistics for GMR in the long run}

\section{Results And Findings}

Table 1: Descriptive Statistics for Geometric Mean Return (GMR) Prices are in Kenya shillings

\begin{tabular}{|l|l|l|l|l|l|l|}
\hline Descriptive elements & P0 & PC & Pt1 & Pt2 & GMR & \\
\hline N( sample size) & 18 & 18 & 18 & 18 & 18 \\
\hline Mean & 17.24 & 34.08 & 12.06 & 16.39 & 0.056 \\
\hline Std. Deviation & 17.92 & 73.46 & 8.77 & 18.43 & 0.31 \\
\hline Minimum & 5.00 & 5.25 & 1.75 & 1.05 & -0.59 & \\
\hline Maximum & 70.00 & 324.00 & 30.25 & 82.00 & 0.62 & \\
\hline Range & 65.00 & 318.75 & 28.50 & 80.95 & 1.20 \\
\hline Skewness & 2.498 & 4.042 & 0.871 & 2.863 & 0.087 & \\
\hline Kurtosis & 5.459 & 16.74 & -0.50 & 10.00 & 0.01 & \\
\hline
\end{tabular}

\section{Source: Researcher, 2017}

Table 1 shows the offer price $\left(\mathrm{P}_{\mathrm{O}}\right)$, the closing price $\left(\mathrm{P}_{\mathrm{C}}\right)$ on the first day of trading, the share prices at end of year one $\left(\mathrm{P}_{\mathrm{t} 1}\right)$ and year two $\left(\mathrm{P}_{\mathrm{t} 2}\right)$. The Geometric Mean Return $(\mathrm{GMR}=0.056)$. The mean prices show that $\mathrm{P}_{\mathrm{C}}$ was the largest price followed by the offer price. The mean prices on the first year were the lowest at ksh. 12.06. Since $\overline{P C}=34.08>\overline{P T 2}=16.39$, the mean prices were lowest in year 2 relative to the prices on the first day of trading. The trend shows that IPO firms, in this study, underperformed.

Table 2: Descriptive Statistics for BHAR Measurements are in percentages, except N, skewness and kurtosis

\begin{tabular}{|l|l|}
\hline Variable & BHAR \\
\hline Observations & 18 \\
\hline Range & 120.46 \\
\hline Minimum & -59.12 \\
\hline Maximum & 61.33 \\
\hline Mean & 5.59 \\
\hline Std. deviation & 31.38 \\
\hline Skewness & 0.081 \\
\hline Kurtosis & 0.030 \\
\hline
\end{tabular}

Source: Researcher, 2017

Table 2 shows the $\overline{B H A R}=5.59 \%$ and the standard deviation of BHAR $=31.38 \%$, while the skewness of $\mathrm{BHAR}=0.081$. 
Do Initial Public Offerings In Kenya Outperform The Market? A Longitudinal Analysis Of Returns.

Table 3: Test Statistics for BHAR

\begin{tabular}{|c|c|c|c|c|c|}
\hline \multicolumn{6}{|c|}{ Test Value for BHAR $=0$} \\
\hline \multirow[t]{2}{*}{$\mathrm{t}$} & \multirow[t]{2}{*}{$\mathrm{df}$} & \multirow[t]{2}{*}{ Sig. (2-tailed) } & \multirow[t]{2}{*}{ Mean Difference } & \multicolumn{2}{|c|}{$95 \%$ Confidence Interval of the Difference } \\
\hline & & & & Lower & Upper \\
\hline .756 & 17 & .460 & 5.593 & -10.011 & 21.20 \\
\hline
\end{tabular}

Source: Researcher, 2017

Table 3 shows P-values $=0.460>0.05$ level of significance. A zero exists between the lower and upper confidence interval.

\section{Conclusions}

Table 3 shows the geometric mean return (GMR) for the IPO was $5.6 \%$, while $\overline{B H A R}$ was $5.59 \%$. The P-values for BHAR $=0.460>0.05$ level of significance. The study concludes that long run performance of IPOs in Kenya do not outperform the Nairobi Securities Exchange (20) Index.Based on the findings, the study upholds that an investor in Initial Public Offerings (IPOs) in Kenya, at best, will receive an investmentreturnequal to the market return.

[1] Barber, B. M., \& Lyon, J. D. (1997). Detecting long run abnormal stock returns: The Empirical power and specification of test sttistics. Journal of financial Economics, 43.

[2] Berk, A. S., \& Peterle, P. (2015). Initial andf long run IPO returns in Central and Eastern Europe. Emerging Markets, Finance and Trade, 51

[3] Brav, A., \& Gompers, P. (1997). Myth or reality? The long run underperformance of IPos: Evidence from venture and nonventure capital backed companies. Journal of Finance, 52.

[4] Gompers, P. A., \& Lerner, J. (2003). The really long run performance of IPos: The pre-NASDAQ Evidence. The journal of Finance, 58(4).

[5] K, p., B, S., \& RJ, B. (n.d.). Privatization initial public offerings in malaysia: Initial premium and long run performance. Pacificbasin Finance Journal, 6 .

[6] M., L. (n.d.). The long run performance of IPOs: the UK experience 1980-1988. Financail managment, 22.

[7] Omran, M. (2005). underpricing and long run performance of share issue privatization in the Egyptian Stock market. The Journal of Financial research, 28(2).

[8] Otero, S. A., \& Mendez, V. M. (2005). The long run underperformance of IPOs: A methodological problem? Revista de Economia Aplicada, 13(37).

[9] Reilly, F. K., \& Brown, K. C. (2009). Investment Analysis and Portfolio Management (9th Edition ed.). South-western Cengage Learning.

[10] Ritter, J. (1991). The lonjg run performance of Initial Public offeriungs. The Journal off finance, 46(1).

[11] s., E., A., G., \& I., T. (1998). Testing the Robustness of long term under performance of UK IPos: Diswcussion paper in Business Management. London.

[12] Strong, n. (1992). Modelling abnormnal returns: A review article. Journal of Business finance3 and accounting, 19(4).

[13] Thomadakis, s., Nounis, C., \& Gounopoulos, D. (2012). Long term performance of Greek IPOs. European Financial Management Journal, 18(1)

[14] Tim, L., \& Jay, R. (1995). The new issues puzzle. Journal of finance, 50(1).

[15] Wamari, E. W. (2014). The effect of IPO on long run stock performance: Evidence from the Nairobi Securities Exchange.nageXCHNAGE. International Journal of scientific and Research publications, 4(10)

\section{APPENDIX 1}

Appendix 1: Offer Prices, Closing Prices, Prices In First And Second Year

\begin{tabular}{|l|l|l|l|l|l|l|l|}
\hline S/N & FIRM & YEAR & PO & PC & Pt1 & Pt2 & GMR \\
\hline 1 & MUMIAS & 2001 & 6.25 & 6.25 & 4.10 & 4.60 & -0.1 \\
\hline 2 & WPP SCAN GRP & 2006 & 20.00 & 15.00 & 30.25 & 25.00 & -0.02 \\
\hline 3 & KENGEN & 2006 & 11.9 & 40.00 & 27.00 & 14.70 & 0.61 \\
\hline 4 & EVEREADY & 2006 & 9.50 & 11.00 & 7.65 & 3.55 & -0.24 \\
\hline 5 & ACCESS KENYA & 2007 & 10.00 & 14.00 & 18.60 & 20.50 & 0.42 \\
\hline 6 & KENYA RE & 2007 & 9.50 & 16.00 & 12.25 & 11.45 & 0.27 \\
\hline 7 & SAFARICOM & 2008 & 5.00 & 7.35 & 4.50 & 4.65 & 0.11 \\
\hline 8 & EQUITY BANK & 2008 & 70.00 & 324.00 & 13.85 & 25.00 & 0.18 \\
\hline 9 & COOPERATIVE BANK & 2008 & 9.50 & 10.45 & 9.00 & 18.95 & 0.3 \\
\hline 10 & CFC (INSURANCE) & 2011 & 17.00 & 14.80 & 6.70 & 82.00 & 0.61 \\
\hline 11 & TRANCENTURY & 2011 & 60.00 & 57.00 & 22.50 & 28.25 & -0.24 \\
\hline 12 & BRIM & 2011 & 9.00 & 8.45 & 5.80 & 14.45 & 0.15 \\
\hline 13 & LONGHORN & 2012 & 14.00 & 16.50 & 13.25 & 8.75 & -0.1 \\
\hline 14 & CIC & 2012 & 7.00 & 5.25 & 5.55 & 9.10 & -0.01 \\
\hline 15 & HOMES AFRICA & 2013 & 12.00 & 25.00 & 4.15 & 1.95 & -0.3 \\
\hline 16 & NSE & 2014 & 18.00 & 16.30 & 23.75 & 16.2 & -0.07 \\
\hline 17 & FLAME TREE & 2014 & 8.00 & 13.85 & 6.45 & 4.95 & 0.02 \\
\hline 18 & ATLAS & 2014 & 13.75 & 12.30 & 1.75 & 1.05 & -0.59 \\
\hline & TOTAL & & $\mathbf{3 1 0 . 4 0}$ & $\mathbf{6 1 3 . 5 0}$ & $\mathbf{2 1 7 . 1 0}$ & $\mathbf{2 9 5 . 1 0}$ & $\mathbf{1 . 0 0}$ \\
\hline & AVERAGE & $\mathbf{1 7 . 2 4}$ & $\mathbf{3 4 . 0 8}$ & $\mathbf{1 2 . 0 6}$ & $\mathbf{1 6 . 3 9}$ & $\mathbf{0 . 0 5 6}$ \\
\hline
\end{tabular}

Source: Researcher, 2017 